\title{
WORKSHOP SISTEM ORGANISASI SANTRI DI PONDOK MODERN DARUL ARQAM PATEAN KENDAL JAWA TENGAH
}

\author{
Djamaluddin Perawironegoro, Hendro Widodo, Suluri, Zunaidi M. Rasid Harahap \\ Universitas Ahmad Dahlan (UAD), Yogyakarta, Indonesia \\ djamaluddin@mpai.uad.ac.id
}

\begin{abstract}
Abstrak: Program pengabdian masyarakat ini bertujuan untuk: (1) meningkatkan pengetahuan santri tentang sistem organisasi yang terdiri dari struktur organisasi, budaya organisasi, manajemen sumber daya manusia, dan tujuan organisasi; (2) meningkatkan kemampuan santri dalam menyusun sistem organisasi yang baik untuk mencapai tujuan organisasi secara efektif dan efisien. Metode yang digunakan dalam pengabdian ini adalah metode ceramah, metode penugasan, metode praktik, dan analisis perbandingan pretest dan posttest. Hasil dari pengabdian ini adalah (1) meningkatnya pengetahuan pengurus tentang pengelolaan organisasi berbasis sistem dengan memberdayakan struktur organisasi yang baik, budaya organisasi yang kuat, dan sumber daya manusia yang direncanakan. Dibuktikan dengan hasil analisis deskriptif rata-rata nilai pretest dan posttest yang meningkat, korelasi dan signifikansi korelasi yang kuat yaitu 0,706 dan 0,000 . Namun pada aspek pengaruh belum menunjukkan nilai pengaruh yang signifikan dengan nilai t hitung 1,220 dan sig. 0,232.; (2) meningkatnya kemampuan santri dalam menyusun kegiatan-kegiatan terkait dengan struktur organisasi, sosialisasi budaya organisasi, pengelolaan sumber daya manusia, dan menentukan visi organisasi. Hasil pengabdian ini menunjukkan bahwa pelatihan sistem organisasi dengan metode workshop dapat meningkatkan pengetahuan dan kemampuan santri dalam berorganisasi sehingga membantu mereka dalam mencapai tujuan organisasi secara efektif dan efisien.
\end{abstract}

Kata Kunci: sistem organisasi; santri; pesantren

\begin{abstract}
The purposes of this community service program are to (1) increase students' knowledge about the organizational system consisting of organizational structure, organizational culture, human resource management, and organizational goals; (2) improve the ability of students to compile a good organizational system which able to achieve organizational goals effectively and efficiently. The method used was the lecture, assignment, practice, and comparative analysis of the pretest and posttest. The results of this community service are (1) the increase of students' knowledge about managing a system-based organization by empowering a good organizational structure, strong organizational culture, and supported the human resources. It is shown by the results of the descriptive analysis where the average score of pretest and posttest get higher, strong correlation and its significance reach 0.706 and 0.000 . However, the aspect of influence has not yet yield a significant value with $t$ value of 1,220 and sig. 0.232 .; (2) the increase of students ability to compile activities related to organizational structure, socialization of organizational culture, management of human resources, and determining the organization's vision. The results of this community service reveal that the organization's training system using the workshop method can improve the knowledge and abilities of students in the organization to help them achieve organizational goals effectively and efficiently.
\end{abstract}

Keywords: organizational system; students; pesantren

\section{Pendahuluan}

Pesantren merupakan lembaga pendidikan agama Islam dengan sistem asrama atau pondok, di mana kyai sebagai figur sentralnya, masjid sebagai pusat kegiatan yagn menjiwainya, dan pengajaran agama Islam di bawah bimbingan kyai yang diikuti santri sebagai kegiatan utamanya (Zarkasyi, 2005). Sebagai suatu lembaga pendidikan, pesantren dikelola 
dengan pendekatan sistemik yaitu integrasi antara pondok, kyai, masjid, pembelajaran agama Islam, dan santri. Elemen-elemen pesantren yang menjadi subsistem dari sistem pendidikan pesantren secara keseluruhan yaitu terdiri dari kyai, santri, pondok, masjid, dan kitab kuning (Dhofier, 2011). Dengan unsur-unsur tersebut, pengklasifikasian ragam pengelolaan pesantren secara administrasi terbagi pada tiga model yaitu tradisional, modern, dan campuran. Model tradisional ditandai dengan kegiatan administrasi yang manual, sedangkan modern ditandai dengan mengoptimalkan teknologi informasi, dan campuran yaitu menggunakan cara manual tetapi berbasis komputer (Khuriyah, 2016).

Perkembangan pesantren dari yang paling sederhana dalam bentuk pengkajian al-Qur'an hingga bentuk pesantren terbesar yang memiliki berbagai unit pendidikan (Ziemek, 1986). Perkembangan dari berbagai unsur pesantren, menjadi bukti bahwa lembaga pendidikan ini memiliki pertumbuhan yang sangat memungkinkan untuk menjadi besar. Hal tersebut sejalan dengan ungkapan yang berimajinasi akan probabilitas pesantren untuk menjadi universitas yang unggul (Madjid, 1997).

Rumusan sistem pesantren mengharuskan keberadaan tujuan, filsafat dan tata nilai, struktur organisasi, penciptaan lingkungan pesantren, interaksi sumber daya manusia pesantren, kyai, guru, santri, dan pengurus, kurikulum pesantren, proses pembelajaran, pengelolaan dana, dan sarana pendidikan (Mastuhu, 1994). Dengan pola pendidikan terpadu menjadikan pesantren sebagai suatu komunitas pembelajar sepanjang hayat. Lebih khusus peran kepemimpinan dalam berbagai level adalah untuk memelihara budaya organisasi melalui proses seleksi sumber daya manusia pesantren, sosialisasi nilai-nilai dan falsafah pesantren, dan prilaku manajemen puncak yang menjadi teladan dari budaya organisasi yang dibangun (Mardiyah, 2012). Internalisasi nilai-nilai pesantren menjadi modal sosial bagi pesantren dalam menggerakkan prilaku individu untuk menciptakan efektifas dan produktifitas kerja. Transformasi nilai menjadi dasar dalam mengelola sistem dan budaya organisasi pesantren (Fauzi, 2017).

Pembaharuan pendidikan pesantren yang menekankan pada perlunya pembaharuan sistem organisasi yang fokus pada tujuan, komunikasi yang baik, otoritas yang jelas dengan memperhatikan dimensi moral dan adaptif terhadap perubahan (Baidlawi, 2006). Interaksi antara kyai dengan guru, kyai dengan santri, guru dengan guru, guru dengan santri, dan santri dengan sesama santri menjadi sarana untuk internalisasi pendidikan pesantren dengan pendekatan kerjasama, sinergi, dan persaudaraan. Hubungan interaksi tersebut berkembang dengan menyusun peraturan untuk berbagai persoalan praktis menggunakan pendekatan prinsip-prinsip organiasasi dan manajemen (Setyaningsih, 2016). Pola interaksi edukatif berlangsung selama santri tinggal di pesantren, pengelolaan dinamika kehidupan santri membutuhkan sistem yang efektif dan efisien dalam bentuk organisasi-organisasi. Sehingga memudahkan ketercapaian tujuan pendidikan pesantren yang menjadi tanggungjawab bersama seluruh warga pesantren sebagai individu, dan unit atau organisasi-organisasi yang dibentuk sebagai suatu kelompok.

Untuk mengelola berbagai sub sistem tersebut, membutuhkan koordinasi dan komunikasi yang tinggi antara seluruh individu dan kelompok dalam pesantren. Demikian itu dengan tujuan 
agar lingkungan pesantren memiliki kontribusi yang positif untuk mencapai tujuan utama pesantren. Secara umum, lingkungan merupakan sumber energi sistem, lingkungan memberikan sumber daya, nilai, teknologi, tuntutan, dan sejarah yang kesemuanya memunculkan tekanan dan memberikan kesempatan bagi aksi organisasional (Hoy \& Miskel, 2014). Robbins menjelaskan pembagian lingkungan pada dua bentuk yaitu lingkungan umum dan lingkungan khusus. Lingkungan umum adalah kondisi yang mungkin mempunyai dampak terhadap organisasi, namun relevansinya tidak begitu jelas. Sedangkan lingkungan khusus adalah bagian dari lingkungan yang secara langsung relevan dengan organisasi dalam mencapai tujuannya (Robbins, 1994).

Dalam perspektif pesantren, lingkungan umum adalah faktor ekonomi, lingkungan sosial, keadaan politik, peraturan perundang-undangan (hukum), kondisi budaya daerah, situasi ekologi dan keamanan negara. Sedangkan lingkungan khusus yang berdampak secara langsung kepada proses pendidikan dan pengajaran adalah asrama, dapur santri, kamar mandi, keamanan, kebersihan lingkungan, kegiatan ekstrakulikuler, kegiatan olah raga, unit kesehatan, koperasi dan kantin santri, masjid, unit bahasa, dan kedisiplinan.
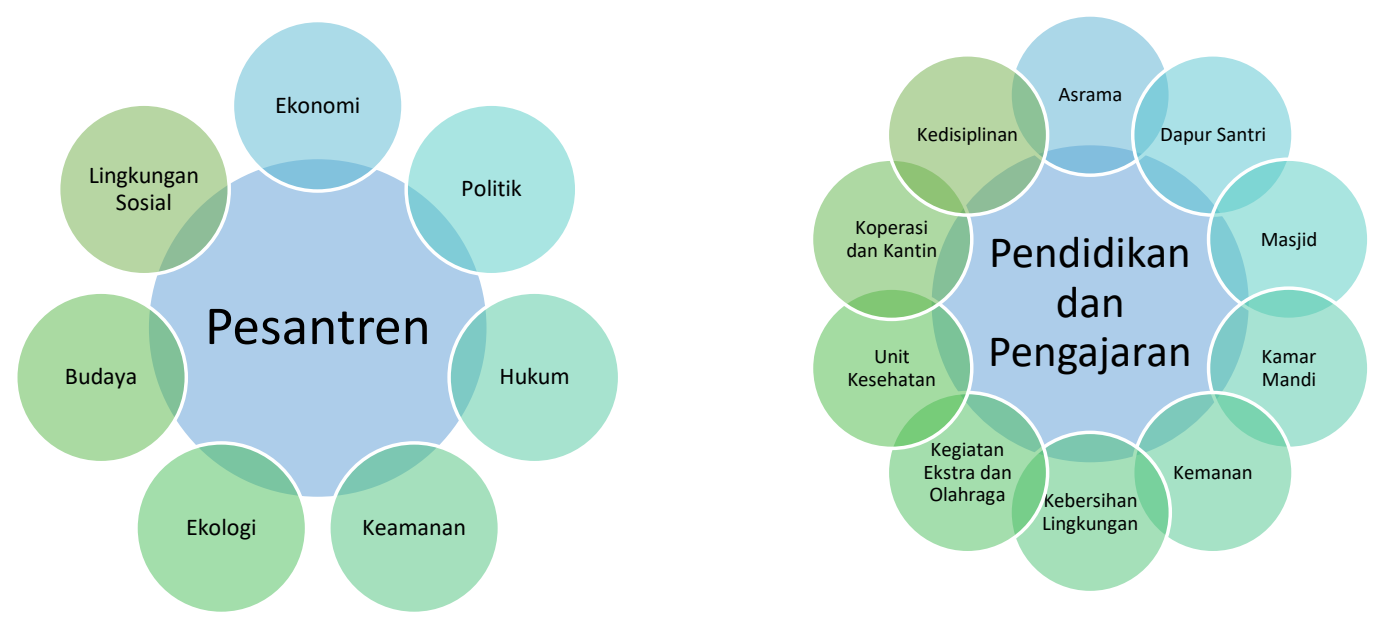

Gambar 1. Lingkungan Umum dan Lingkungan Khusus Pesantren

Deskripsi lingkungan khusus pesantren yang kompleks sebagaimana pada gambar 1 dapat dipahami bahwa dinamika organisasi pesantren merupakan suatu model organisasi yang kompleks yang antara satu dengan yang lain memiliki keterkaitan dan keterhubungan dengan yang lain. Kompleksitas tersebut diatasi oleh pengelola pesantren dengan membuat struktur organisasi pesantren, mengelola budaya organisasi pesantren, dan melakukan manajemen sumber daya manusia bagi para pengurus pesantren. Royani menjelaskan bahwa untuk mencapai tujuan pesantren dibutuhkan tindakan strategis yaitu memadukan dan mengintegrasikan subsistem-subsistem pesantren, dengan memberdayakan nilai-nilai yang menjadi budaya dan keunggulan pesantren (Royani, 2018).

Implementasi manajemen pendidikan di pesantren memiliki manfaat yang signifikan, yaitu dapat meningkatkan mutu santri. Melalui proses perencanaan, pengorganisasian, 
kepemimpinan dan pengawasan. Mutu santri yang dihasilkan yaitu kompetensi prilaku yang berdasarkan atas nilai-nilai keimanan dan ketaqwaan melalui kegiatan-kegiatan pengembangan diri workshop, pengajian, seminar, pembuatan karya ilmiah, halaqah, dan latihan ceramah (Yatimah, 2011). Lingkungan kerja, budaya organisasi, dan kepemimpinan juga memiliki pengaruh yang signifikan terhadap kinerja pegawai (Widodo, 2010).

Berdasarkan observasi penulis, banyak pesantren belum memberikan perhatian terhadap pengelolaan lingkungan berbasis kelompok. Demikian itu dapat dilihat dari dinamika kegiatan kokurikuler yang melibatkan santri dan warga pesantren. Pada aspek kontinuitas kegiatan, yaitu cenderung atau bahkan bisa dikatakan sering terjadi ketergantungan pada kuatnya motivasi pengurus untuk menyelenggarakan suatu kegiatan. Saat motivasi itu tinggi, maka kegiatan itu berjalan dengan baik dan maksimal. Sebaliknya, pada saat motivasi itu rendah kegiatan tersebut tidak berjalan dengan baik dan mungkin lambat laun akan ditiadakan dengan asumsi ketidakterlaksanaan kegiatan.

Departemen atau bidang khusus yang bertanggungjawab terhadap kegiatan di luar sekolah adalah pengasuhan santri. Secara perhitungan waktu, para santri belajar di dalam ruang kelas hanya antara 7 - 8 jam, sedangkan selebihnya berada di luar kelas. Di sini peran staf pengasuhan santri menjadi penting untuk memastikan bahwa waktu yang tersisa yaitu antara 16 - 17 jam dapat dimanfaatkan dengan baik untuk mendukung keterlaksanaan proses pendidikan dan pengajaran, mengisi waktu-waktu tersebut dengan kegiatan yang produktif dan terukur.

Pondok Modern Darul Arqam Putra Patean Kendal memiliki staf pengasuhan santri yang berjumlah 5 orang, sedangkan jumlah santri secara keseluruhan berjumlah 500 -an santri putra. Pada pengelolaan santri, staf pengasuhan santri dibantu oleh Organisasi Santri Darul Arqam (OSDA). Organisasi ini dikelola oleh santri senior yang mendapatkan mandat dan amanah untuk mengisi unit-unit yang berjumlah 15 bagian, yaitu; Pengurus Harian dan Keamanan, Dapur Santri, Ta'mir Masjid, Olah Raga, Kebersihan Lingkungan, Wali Asrama, Kesenian dan Keterampilan, Bahasa, Pengumuman, Pengajaran, Kantin, Koperasi, Kesehatan, Penerimaan Tamu, dan Hizbul Wathan.

Kepengurusan OSDA bukan tanpa masalah yang berdampak pada kinerja yang kurang optimal. Disampaikan oleh pengurus pesantren bahwa problem yang ditemui adalah tingkat motivasi para pengurus yang rendah dalam menjalankan organisasi yang dalam hal ini adalah keterlaksanaan kegiatan-kegiatan yang menunjang kegiatan intra kulikuler. Demikian itu dapat dilihat bahwa hampir semua kegiatan organisasi harus selalu dikontrol dan diingatkan. Jika lengah, maka kemungkinannya adalah program kerja yang tidak berjalan optimal atau bahkan tidak berjalan.

Fokus orientasi santri ke pesantren adalah untuk belajar yang dimaknai belajar di sekolah, mengarahkan para santri pada tugas utama yang sangat penting yaitu belajar pelajaran di kelas. Sedangkan kegiatan pendidikan di luar kelas merupakan suplemen untuk meningkatkan kapasitas dan kemampuan diri, menjadi bukan hal yang fardhu. Sehingga, beberapa santri lebih mementingkan pembelajaran daripada menggerakkan organisasi.

Problem yang ditemukan oleh peneliti berdasarkan observasi dan wawancara sederhana 
di pesantren bersama para pengurus adalah masalah sinergi antar unit bagian dan kinerja antar unit bagian untuk selalu berkesinambungan. Problem kinerja ditunjukkan bahwa unit-unit yang ada belum berusaha optimal dalam mengelola unit yang diamanahkan. Demikian itu nampak pada uraian pengurus pesantren yang menyatakan bahwa kinerja yang sudah dilakukan belum memberikan kepuasan kepada stake holder pesantren belum sesuai dengan yang diharapkan. Sebagai contoh adalah kinerja Bagian Bahasa yang belum optimal, dibuktikan dengan milieu berbahasa asing yang belum terbentuk dengan baik. Yaitu santri-santri tidak berkomunikasi dengan Bahasa asing sebagaimana diharapkan. Bagian-bagian lain pun memiliki masalah keberlanjutan kegiatan yang tidak konsisten.

Problem sumber daya manusia masih menjadi problem pokok, lebih khusus di staf pengasuhan santri. Sifat staf pengasuhan santri yang adalah guru pengabdian memiliki kelemahan dalam keberlanjutan untuk mengabdi di pesantren. Pada umumnya, guru pengabdian yang telah menyelesaikan masa pengabdiannya (1 tahun minimal), guru itu pulang untuk mengabdi pada masyarakatnya atau melanjutkan studi di luar pesantren. Tingginya tingkat keluar-masuk stafpengasuhan santri berimplikasi pada keberlanjutan program yang telah baik dan sudah berjalan.

Berdasarkan kondisi analisis situasi di lingkungan pesantren, ditemukan pendekatan struktural digunakan oleh pengelola pesantren untuk menggerakkan santri hidup bersama mencapai tujuan santri dan pesantren, namun peran struktur organisasi yang dibangun belum maksimal. Adapun pendekatan budaya organisasi digunakan untuk menggerakkan dinamika santri agar turut bekerjasama dengan meminimalisir formalisasi, namun budaya organisasi yang dibangun belum memiliki efektif dalam metode sosialisasi. Sedangkan, pola pengembangan sumber daya manusia berjalan dengan baik di pesantren, akan tetapi masih memiliki kendala dalam mempersiapkan, mengembangkan, dan mempertahankan sumber daya manusia yang dimiliki. Kegiatan pengabdian masyarakat ini bertujuan untuk meningkatkan pengetahuan pengurus OSDA tentang sistem organisasi santri yang terdiri dari perumusan visi-misi dan tujuan organisasi, penyusunan struktur organisasi, pengelolaan budaya organisasi, dan manajemen sumber daya manusia.

\section{Metode}

Berdasarkan analisis permasalahan dan permasalahan mitra, solusi yang ditawarkan kepada pengurus pesantren adalah:

a. Memberikan pemahaman mengenai pola interaksi antara subsistem-subsistem organisasi untuk mencapai tujuan pesantren.

b. Memberikan wawasan mengenai elemen-elemen struktur organisasi, sosialisasi budaya organisasi, dan implementasi manajemen sumber daya manusia di pesantren.

Adapun pemecahan masalah-masalah organisasi dilakukan dengan beberapa pendekatan yang dilakukan secara bersama-sama yaitu:

a. Berbasis struktural, yaitu seluruh kegiatan pengabdian masyarakat dilakukan dengan memberikan kesempatan kepada para pembimbing dan pengambil kebijakan bagi OSDA. 
b. Berbasis kelompok pengurus OSDA, seluruh kegiatan pengabdian masyarakat dilakukan dengan melibatkan seluruh bagian OSDA sebagai pembelajar melalui kegiatan perencanaan, workshop, sosialisasi, pendampingan, dan evaluasi.

c. Komprehensif seluruh kegiatan dilakukan secara serentak melibatkan para pengurus OSDA dalam pelatihan dan pendampingan jalannya organisasi.

d. Berbasis nilai-nilai dan tradisi Pondok Modern Darul Arqam Patean.

Selanjutnya empat pendekatan tersebut dimplementasikan dalam empat tahapan; 1) Analisis Kebutuhan; 2) Penyusunan tujuan pelatihan; 3) Membuat rincian program; 4) Monitoring dan Evaluasi program. Analisis kebutuhan dilakukan dengan melakukan observasi dan wawancara kepada para pengurus dan pengelola pesantren tentang kendala dan problem dalam pengelolaan organisasi santri. Hasil observasi dan wawancara tersebut menjadi dasar untuk merumuskan tujuan penelitian. Tujuan pelatihan atau workshop merupakan petunjuk atau arah yang akan dicapai oleh penyelenggara, oleh karena itu tujuan workshop ini adalah untuk memberikan pengetahuan sistem pengelolaan organisasi di pesantren.

Rincian program disusun untuk memudahkan pengorganisasian kegiatan, yang dalam hal ini adalah membagi kegiatan workshop pada empat tema pokok yaitu menyusun visi, misi, dan tujuan organisasi, membangun struktur organisasi, mengelola dan mensosialisasikan budaya organisasi, dan pengelolaa sumber daya manusia.

Sebagai bentuk evaluasi kegiatan, dilakukan pretest untuk mengetahui kapasitas pengetahuan para peserta terhadap pengelolaan sistem organisasi, kemudian di akhir dilakukan posttest. Nilai pretest dan posttest tersebut dikumpulkan dan dianalisa untuk dijadikan sebagai indikator keberhasilan kegiatan workshop.

Sasaran dari program pengabdian ini adalah pengurus Organisasi Santri Darul Arqam (OSDA) putra yang berjumlah 50 santri, namun pada proses pelaksanaan terdapat 10 santri yang tidak hadir, adapun pengurus santri putri berjumlah 58 santri.

Keberhasilan kegiatan workshop dilihat dari hasil pretest dan posttest. Demikian itu dengan maksud untuk mengetahui tingkat keberhasilan kegiatan workshop yang diselenggarakan. Yang kemudian penulis memilih 31 santri untuk dijadikan sebagai sampel yang akan dibandingkan nilainya antara pretest dan posttest.

Data pada kegiatan ini dikumpulkan dengan melalui kuesioner, sebagaimana diungkapkan Sugiyono, teknik kuesioner atau angket adalah pengumpulan data yang dilakukan dengan cara memberi seperangkat pertanyaan atau pernyataan tertulis kepada responden untuk dijawabnya (Sugiyono, 2008). Variabel yang digunakan terdiri dari kejelasan visi, misi, dan tujuan organisasi, keterlaksanaan struktur organisasi, keberadaan dan sosialisasi budaya organisasi, dan kinerja manajemen sumber daya manusia. Berbagai variabel tersebut dijabarkan dan disusun untuk kemudian dijadikan pernyataan pada angket. Setiap pernyataan yang dipilih oleh responden (peserta) dihitung menggunakan skala Likert 1-5. Selanjutnya data yang ada diakumulasi menjadi nilai pretest dan posttest para peserta.

Jenis data pada kegiatan pengukuran keberhasilan workshop system organisasi santri adalah data rasio, yaitu data yang bersifat angka dalam pengertian yang sesungguhnya, yang juga dapat dioperasikan secara matematis. Data rasio dihasilkan dari jumlah nilai jawaban 
responden dari pernyataan yang diberikan. Pada angket yang didistribusikan, terdapat 27 pernyataan dengan skala minimum adalah poin 1 dan maksimum 5 pada setiap pernyataan. Sehingga poin minimal yang didapatkan oleh responden adalah 27 dan maksimal adalah 135.

Analisis data workshop ini menggunakan analisis deskriptif dan analisis inferensial. Analisis deskriptif di sini dimaksudkan untuk memberikan gambaran deskripsi singkat hasil penilaian responden pada aspek rata-rata pretest dan posttest. Sedangkan analisis inferensial, dilakukan untuk membandingkan antara nilai pretest dan posttest dengan menyusun hipotesis dan menggunakan uji statistik perbandingan. Pada kegiatan ini dilakukan dengan Uji t Sample Berpasangan atau Paired Sampel t-Test, memanfaatkan aplikasi SPSS 23.

\section{Hasil dan Pembahasan}

Pengabdian masyarakat ini dilakukan oleh dosen dan mahasiswa Magister Pendidikan Agama Islam Universitas Ahmad Dahlan Yogyakarta. Kegiatan diselenggarakan dengan kerjasama antara dosen, mahasiswa, program studi Pendidikan Agama Islam, Lembaga Penelitian dan Pengabdian Masyarakat (LPPM UAD), dan Pondok Modern Darul Arqam Patean Kendal Jawa Tengah sebagai mitra, yang pada hari itu dihadiri oleh Kholiq Kurniawan, M.Pd.I sebagai direktur pesantren. Terdapat 40 santri putra dan 58 santri putri pengurus Organisasi Santri Darul Arqam (OSDA) yang terlibat aktif dalam kegiatan ini.

Acara dilangsungkan pada hari Kamis 9 Mei 2019 di Masjid Pesantren Darul Arqam pada pukul 08.00 hingga pukul 14.00. Kegiatan workshop dibagi dalam empat sesi; menyusun visimisi dan tujuan organisasi, menyusun struktur organisasi, mengelola budaya organisasi, dan pengelolaan sumber daya manusia. Untuk mendapatkan gambaran singkat pengetahuan para pengurus tentang berbagai tema tersebut, angket pretest disebarkan kepada beberapa peserta, yang kemudian dikembalikan, direkap, dan dihitung sebagai data awal kegiatan.

Lazimnya suatu organisasi formal adalah memiliki visi, misi, dan tujuan. Keberadaan visi dan misi memberikan keuntungan seperti; 1) memastikan kepaduan tujuan dalam organisasi; 2) menyediakan landasan untuk mengalokasikan sumber daya organisasi; 3) membangun iklim organisasi yang terpadu; 4) menjadi titik fokus bagi warga organiasi agar serjalan dengan maksud dan tujuan organisasi; 5) memfasilitasi translasi dari tujuan menjadi struktur kerja yang melibatkan pembagian tugas ke elemen-elemen yang bertanggung jawab dalam organisasi; dan 6) menjelaskan maksud-maksud organisasional dan kemudian ditranslansikan dalam berbagai tujuan yang menjadi parameter biaya, waktu, dan kinerja yang dapat dikontrol (Yunus, 2016).

Oleh karena pentingnya keberadaan visi-misi dan tujuan organisasi, maka perlu bagi pengurus OSDA untuk mengetahui bagaimana hal tersebut disusun dan diikrarkan. Tahapan penyusunan adalah sebagai berikut; 1) mengkaji makna visi pesantren yang menjadi lembaga utama tujuan para santri masuk ke pesantren; 2) menginventarisasi rumusan tugas dan fungsi santri dalam komunitas pesantren 3) rumusan tugas dan fungsi tersebut, dirangkum dan dirumuskan kembali menjadi konsep rumusan visi organisasi santri; 4) rumusan visi didiskusikan dengan seluruh warga pesantren untuk memperoleh masukan, dan saran-saran; 5) rumusan visi dikomunikasikan dengan seluruh warga pesantren guna memperoleh penyempurnaan; dan 
6) rumusan visi yang telah menjadi kesepakatan ditetapkan dengan keputusan pimpinan pesantren, sehingga menjadi milik bersama, mendapat dukungan dan komitmen seluruh warga pesantren.

Visi, misi, dan tujuan tersebut tidak dapat dicapai jika tidak memberdayakan alat-alat untuk menggerakkan organisasi. Faktor yang penting untuk mencapai tujuan organisasi adalah struktur organisasi, budaya organisasi, dan manajemen sumber daya manusia. Tiga hal ini merupakan sistem organisasi yang bergerak secara bersama-sama untuk mencapai tujuan organisasi yang dalam hal ini adalah pesantren.

Usman mendefinisikan struktur organisasi sebagai sistem formal dari hubungan aturanaturan dan tugas serta keterkaitan otoritas yang mengontrol tentang cara orang bekerja sama dan memanfaatkan sumber daya untuk mencapai tujuan organisasi (Usman, 2011). Pidarta mendefinisikan sebagai mekanisme kerja organisasi itu yang menggambarkan unit-unit kerjanya dengan tugas-tugas individu di dalamnya beserta kerja samanya dengan individu-individu lain dan hubungan antara unit-unit kerja itu baik secara vertikal maupun horizontal (Pidarta, 2011). Dengan demikian, struktur organisasi dapat dipahami sebagai suatu sistem formal yang terdiri dari pembagian tugas, pengelompokan pekerjaan, sistem pelaporan, pengawasan, standarisasi tugas, dan pengambilan keputusan.

Pada organisasi santri tidak semua elemen tersebut diimplementasikan dalam pengelolaan organisasi. Berdasarkan observasi, organisasi santri berbentuk organisasi dengan struktur yang sederhana yang tidak rigid dalam pengelolaannya. Demikian itu diketahui dari diagram struktur organisasi yang dibuat dan program kerja yang telah disusun. Sehingga pada kegiatan workshop di aspek struktur organisasi, elemen organisasi yang diajarkan dan dipraktekkan adalah mencakup tiga hal; pembagian kerja, wewenang, dan formalisasi. Pembagian pekerjaan ialah tingkat pekerjaan dirincikan, dijelaskan dan dikelompokkan dalam suatu kelompok kegiatan sejenis agar setiap individu dalam organisasi bertanggung jawab melaksanakan tugas masing-masing. Wewenang adalah hak yang diserahkan kepada seseorang dalam organisasi untuk melakukan sesuatu atau memerintah orang lain agar mencapai tujuan tertentu. Sedangkan, formalisasi adalah tingkat dimana pekerjaan di dalam sebuah organisasi distandarkan.

Berdasarkan pemahaman yang baik tentang struktur organisasi dan elemen-elemen yang menjadi fungsi struktur organisasi, diharapkan struktur organisasi santri memberikan fungsi kekhasan ciri-ciri organisasi yang dapat digunakan untuk mengendalikan para pengurus untuk bekerjasama dalam mencapai tujuan. Koordinasi dan motivasi yang diberikan oleh pimpinan berdasarkan hirarki wewenang dapat lebih terarah dan sesuai dengan pembagian tugas yang diberikan. Formalisasi yang menjadi standar dalam melakukan suatu kegiatan, memberikan arah bagi para pengurus bagaimana pekerjaan dijalankan. Dengan struktur yang baik dan jelas dapat merespon pemanfaatan lingkungan, teknologi, dan sumber daya manusia. Demikian itu berimplikasi pada pengembangan organisasi santri.

Sikap dan prilaku warga organisasi dipengaruhi oleh pengelolaan dan pengembangan budaya organisasi warga sekolah. Budaya organisasi dibangun oleh bias dan asumsi para pimpinan organisasi yang kemudian dianggap sebagai cara yang benar dalam bersikap dan 
berinteraksi secara bersama (Robbins, 1994). Demikian itu menunjukkan bahwa budaya organisasi dibangun secara sadar oleh para pimpinan dan pengelola organisasi yang berfungsi menggerakkan dinamika organisasi untuk mencapai tujuan.

Widodo (2019) mengungkapkan bahwa budaya sekolah adalah pola pengetahuan, filosofi bersama, ideologi, keyakinan, nilai, asumsi, harapan, norma, simbol, perilaku, sikap keterampilan, dan kebiasaan maupun material artifak yang diterima bersama, serta dilaksanakan dengan penuh pesadaran oleh warga sekolah baik oleh kepala sekolah, guru, karyawan siswa, maupun orang tua siswa yang menjadi pedoman prilaku warga sekolah dan menjadi identitas sekolah yang membedakan dengan sekolah lain.

Usman (2011) mengungkapkan praktik ketiga tingkatan budaya organisasi dalam organisasi sekolah adalah; 1) Artifak (yang tampak) seperti fisik sekolah, perilaku; 2) nilai-nilai yang didukung seperti; bekerja sinergi, harmonis, dan sebagainya; dan 3) asumsi dasar yang mendasari. Dalam perspektif pesantren artifak dimaknai adalah segala sesuatu yang dapat dilihat, didengar, dan dirasakan oleh para pengurus dan santri seperti warna gedung, nilai-nilai atau falsafah yang dituliskan pada bangunan sekolah, logo pesantren, dan lain-lain. Nilai-nilai yang didukung adalah nilai-nilai yang disimpulkan dari cerita berdasarkan fakta bagaimana nilainilai pesantren diperjuangkan dan dipedomani sebagai cara yang benar seperti nilai keikhlasan, kesederhanaan, berdikari, ukhuwwah Islamiyah, dan kebebasan dari pendiri dan pengurus pesantren. Adapun asumsi-asumsi dasar adalah pengetahuan, simpulan pengalaman dan aktifitas yang didapatkan oleh pendiri dan pengurus, yang dari hal tersebut merepresentasikan nilai-nilai dan artifak dalam kehidupan sehari-hari.

Keberadaan budaya pesantren membutuhkan sosialisasi kepada warga pesantren untuk ditiru dan diimplementasikan dalam berintegrasi antara warga pesantren dan bersikap terhadap warga di luar pesantren. Sosialisasi budaya pesantren diungkapkan oleh Zarkasyi melalui beberapa cara yaitu; keteladanan, penciptaan lingkungan, pengajaran, pengarahan, penugasan, dan pembiasaaan (Zarkasyi, 2005).

Kepada pengurus organisasi santri diharapkan mengetahui bagaimana budaya pesantren dibangun, disosialisasikan, dan diinternalisasikan kepada para santri. Mengingat mereka sebagai pengurus, maka perlu kiranya bagi mereka untuk memahami betul nilai-nilai dan falsafah pesantren. Lalu kemudian nilai-nilai tersebut difahami, diinternalisasi, dan diamalkan dalam bekerja mengelola organisasi. Kemudian dalam pemberian tugas-tugas kepada seluruh santri menjadi cara dalam membiasakan nilai-nilai dan falsafah pesantren.

Tindakan-tindakan penjagaan budaya organisasi dilakukan dengan proses seleksi (Robbins, 1994). Seleksi dimaksudkan agar organisasi mendapatkan orang-orang yang memiliki pengetahuan, pengalaman, dan sikap yang selaras dengan budaya yang dibangun. Kesesuaian ini menjadi penting, mengingat frekwensi keluar-masuk pegawai dipengaruhi oleh kesesuaian antara budaya individu dengan budaya organisasi di tempat kerja.

Pengelolaan atau manajemen sumber daya manusia di organisasi santri pun perlu untuk diperhatikan oleh pengurus. Manajemen sumber daya manusia sebagai sinergi aktivitasaktivitas yang memfasilitasi orang-orang di dalam organisasi untuk berkontribusi dalam pencapaian rencana strategis organisasi. Aktifitas tersebut terdiri dari perencanaan sumber daya 
manusia, seleksi, penempatan, pelatihan dan pengembangan, penilaian kinerja, dan kompensasi.

Tujuan dan fungsi dari kegiatan manajemen sumber daya manusia pada organisasi santri adalah; 1) untuk mendapatkan dan mempertahankan SDM yang cakap, dapat dipercaya, dan memiliki motivasi; 2) untuk meningkatkan dan memperbaiki kapasitas SDM; 3) memotivasi SDM dalam bekerja; dan 4) untuk menciptakan iklim kerja yang sinergi dan harmonis

Pada pengelolaan pesantren berbagai kegiatan manajemen sumber daya manusia dilakukan secara natural bersamaan dengan berbagai program kegiatan yang diselenggarakan. Kegiatan manajemen SDM meliputi; perencanaan, seleksi, pelatihan dan pengembangan, bimbingan, dan penilaian kinerja. Perlu diketahui bahwa kompensasi yang diberikan bagi pengurus organisasi santri bukan bersifat materi, tetapi lebih bersifat maknawi yaitu pengetahuan dan pengalaman mengelola organisasi. Amanah sebagai pengurus merupakan salah satu cara pesantren memberikan pendidikan yang sangat berharga untuk kehidupan santri nanti pada saat lulus pesantren. Tak jarang, lulusan pesantren pada saat kembali ke masyarakat bekerja sebidang dengan pengalamannya saat menjadi pengurus organisasi santri.

Berbagai pengetahuan tentang proses visi-misi dan tujuan dibangun, struktur organisasi diberdayakan, budaya organisasi yang disosialisasikan, dan manajemen sumber daya manusia yang disampaikan kepada para pengurus OSDA. Pengetahuan tentang berbagai faktor pendukung dinamika organisasi menjadi kebutuhan dengan asumsi bahwa pengetahuan yang baik dan benar tentang bagaimana organisasi digerakkan, kiranya dapat memberikan wawasan dan kesadaran untuk menggerakkan organisasi secara aktif dan positif.

Berikut adalah analisis hasil pretest dan posttest kegiatan workshop sistem organisasi santri di Pondok Modern Darul Arqam Patean Kendal.

Tabel.1. Perbandingan Deskriptif

Paired Samples Statistics

\begin{tabular}{|ll|r|r|r|r|}
\hline & & Mean & \multicolumn{1}{|c|}{$\mathrm{N}$} & Std. Deviation & \multicolumn{1}{c|}{ Std. Error Mean } \\
\hline Pair 1 & Pretest & 115.48 & 31 & 10.832 & 1.945 \\
& Posttest & 117.26 & 31 & 10.231 & 1.837 \\
\hline
\end{tabular}

Sumber: Olah data kegiatan

Pada output tabel 1 dapat dilihat bahwa hasil statistik rata-rata kinerja santri dalam menjalankan organisasi pada saat sebelum dilakukan pelatihan adalah 115,48 . Sedangkan untuk hasil nilai paska pelatihan atau post test diperoleh nilai 117,26 . Jumlah responden yang digunakan pada kegiatan pengabdian ini adalah 31 responden dari total populasi sebanyak 97 responden. Dengan meningkatnya nilai rata-rata antara pretest $115,48<$ posttest 117,26 , demikian secara deskriptif menunjukkan peningkatan pengetahuan peserta workshop. Selanjutnya untuk membuktikan signifikansi peningkatan tersebut, maka dilakukakn uji paired sample $t$ test yang terdapat pada tabel output berikut: 
Tabel 2. Korelasi Pretest dan Posttest Paired Samples Correlations

\begin{tabular}{|ll|l|r|c|}
\hline & $\mathrm{N}$ & Correlation & Sig. \\
\hline Pair 1 $\quad$ Pretest \& Posttest & 31 & .706 & .000 \\
\hline
\end{tabular}

Sumber: Olah data kegiatan

Sedangkan pada output tabel 2 paired samples correlations menunjukkan hasil uji korelasi atau hubungan antara kedua data variable pretest dan posttest. Berdasarkan output tersebut dapat diketahui nilai koefisien korelasi sebesar 0,706 dengan nilai signifikansi 0,000. Nilai signifikansi yang lebih kecil dari probabilitias 0,05, maka dapat dikatakan bahwa ada hubungan antara variable pretest dan dan variable posttest.

Hipotesis penelitian yang diajukan pada analisis perbandingan antara pretestdan posttest adalah sebagai berikut:

$\mathrm{H}_{0}=$ Tidak ada perbedaan rata-rata antara hasil pretest dengan posttest kinerja sistem organisasi santri yang dapat diartikan bahwa tidak ada pengaruh pelaksanaan workshop yang dilakukan antara sebelum dan sesudah dilaksanakannya.

$\mathrm{H}_{\mathrm{a}}=$ Ada perberdaan rata-rata antara hasil pretest daengan posttest kinerja organisasi santri yang dapat diartikan bahwa pelaksanaan workshop turut meningkatkan kinerja organisasi santri di Pondok Modern Darul Arqam Patean Kendal Jawa Tengah.

Tabel 3. Uji Paired Samples Test

Paired Samples Test

\begin{tabular}{|c|c|c|c|c|c|c|c|c|c|}
\hline & \multicolumn{5}{|c|}{ Paired Differences } & \multirow[t]{3}{*}{$\mathrm{t}$} & \multirow[t]{3}{*}{$\mathrm{df}$} & \multirow{3}{*}{$\begin{array}{c}\text { Sig. } \\
\text { (2-tailed) }\end{array}$} \\
\hline & & \multirow[t]{2}{*}{ Mean } & \multirow[t]{2}{*}{$\begin{array}{c}\text { Std. } \\
\text { Deviation }\end{array}$} & \multirow[t]{2}{*}{$\begin{array}{c}\text { Std. Error } \\
\text { Mean }\end{array}$} & \multicolumn{2}{|c|}{$\begin{array}{l}95 \% \text { Confidence Interval } \\
\text { of the Difference }\end{array}$} & & & \\
\hline & & & & & Lower & Upper & & & \\
\hline Pair 1 & $\begin{array}{l}\text { Pretest - } \\
\text { Posttest }\end{array}$ & -1.774 & 8.098 & 1.454 & -4.745 & 1.196 & -1.220 & 30 & .232 \\
\hline
\end{tabular}

Sumber: Olah data kegiatan

Pada tabel 3. paired samples test dapat dilihat bahwa nilai Sig. (2-tailed) adalah sebesar 0,232 > 0,05. Demikian itu dapat dimakna HO diterima dan Ha ditolak. Sehingga dapat disimpulkan bahwa tidak ada perbedaan rata-rata antara antara hasil pretest dan posttest kinerja sistem organisasi santri. Dengan kata lain, bahwa tidak ada pengaruh pelaksanaan workshop yang dilakukan di pondok modern Darul Arqam Patean Kendal Jawa Tengah.

Pada tabel Paired Samples Test kolom uji t menunjukkan angka sebesar -1,220. T hitung bernilai negatif disebabkan oleh nilai rata-rata pre test lebih rendah daripada pada rata-rata nilai post test. Nilai yang negative ini, dapat juga dimaknai sebagai nilai yang positif. Nilai $t$ hitung $1,220<$ dari nilai $\mathrm{t}$ tabel sebesar 2,045 menunjukkan suatu kesimpulan terima HO dan tolak Ha. Yaitu bahwa perbedaan nilai antara hasil pretest dan post testmenunjukkan ketiadaan pengaruh yang diberikan. 
Berdasarkan hitungan statistik yang telah dilakukan, secara deskriptif terdapat peningkatan pengetahuan sistem organisasi santri pada pengurus OSDA yaitu sebagaimana ditunjukkan peningkatan rata-rata nilai dari hasil pretest dan posttest. Demikian juga jika dilihat dari hubungan korelasi, kegiatan workshopyang dilakukan memiliki hubungan yang kuat antara sebelum dan sesudah dilaksanakannya kegiatan yaitu sebesar 0,706 yang juga memiliki nilai signifikansi 0,000 yang menunjukkan hubungan tersebut kuat dan signifikan.

Akan tetapi jika melihat uji hipotesis yang telah dilakukan, nilai pretestdan posttest belum menunjukkan pengaruh yang signifikan sebagaimana pada uji paired sample test yang menunjukkan nilai signifikansi 0,232 dan nilai uji t yang menunjukkan angka 1,220. Yang memiliki arti bahwa workshop yang diselenggarakan tidak berpengaruh secara signifikan antara sebelum dan sesudah. Demikian itu dapat dimengerti, mengingat jarak waktu kegiatan yang dilangsungkan belum sampai pada tahap implementasi.

Oleh karena itu, untuk meningkatkan hasil pengaruh kegiatan workshop diperlukan kegiatan implementasi yang juga diberikan pendampingan dan monitoring. Dengan harapan pengetahuan yang diberikan turut memberikan perubahan prilaku pengelolaan sistem organisasi santri di Pondok Modern Darul Arqam Patean Kendal.

\section{Kesimpulan}

Pesantren sebagai suatu sistem yang terpadu antara model pendidikan formal, informal, dan nonformal memiliki kompleksitas yang tinggi untuk mewujudkan pola pendidikan yang terstruktur dan terencana. Keberhasilan pengelolaan tersebut berimplikasi pada nilai-nilai yang akan menjadi karakter dalam kehidupan santri pada masa-masa yang akan datang, mengingat dinamika kehidupan santri yang 24 jam penuh berada dalam lembaga pesantren dan dalam bimbingan para pengurus dan kyai dan guru-guru pesantren.

Menciptakan lingkungan yang baik menjadi tanggung jawab seluruh warga pesantren dan lebih utama para pimpinan pesantren. Oleh karena itu, perlu bagi pengelola dan pengurus pesantren untuk memberdayakan sub sistem pesantren yaitu organisasi santri. Kepada para pengurus juga perlu untuk mengetahui bagaimana organisasi digerakkan untuk mencapai tujuan organisasi tersebut secara khusus, dan tujuan pesantren secara umum.

Berdasarkan kegiatan pengabdian masyarakat yang telah dilakukan, disimpulkan berbagai hal berikut: 1) Merupakan hal yang penting bagi setiap bagian OSDA untuk menyusun visi, misi, dan tujuan, struktur organisasi dengan kejelasan program, kegiatan dan tugas setiap bagian, memiliki budaya organisasi dan mensosialisasikannya, dan manajemen sumber daya manusia yang baik; 2) Terdapat peningkatan pengetahuan pengurus OSDA terkait visi-misi, struktur organisasi, budaya organisasi, dan manajemen SDM. 3) Peningkatan pengetahuan santri tersebut diketahui dari nilai rata-rata pretest dan posttest yang meningkat dengan korelasi yang kuat yaitu 0,706 dan signifikansi korelasi yaitu 0,000. Korelasi tersebut belum menunjukkan siginifikansi pengaruh yang diberikan dimana nilai t hitung $(1,220)$ lebih kecil dari $t$ tabel dan nilai sig. yang lebih besar dari standar yang ditentukan $(0,232>0,005)$.

Berdasarkan pengetahuan dan hasil perbandingan nilai pretest dan posttest dapat 
dilakukan kegiatan pendampingan atau pembinaan agar memberikan pengaruh dalam pelaksanaan sehari-hari. Pembiasaan ini akan mengarahkan pengurus OSDA untuk selalu mengevaluasi dan melakukan perbaikan-perbaikan secara berkelanjutan.

\section{Referensi}

Baidlawi, M. (2006). Modernisasi Pendidikan Islam. Tadris, 1(2), 154-167.

Dhofier, Z. (2011). Tradisi Pesantren: Studi Pandangan Hidup Kyai dan Visinya Mengenai Masa Depan Indonesia. Jakarta: LP3ES.

Fauzi, A. (2017). Manajemen Pendidikan Islam di Pesantren; Berbasis Kearifan Lokal Kajian Fenomenologis. Seminar Nasional Pendidikan, Fakultas IImu Pendidikan Universitas Negeri Malang Sinergitas Keluarga, Sekolah Dan Masyarakat Dalam Penguatan Pendidikan Karakter, 51-62.

Hoy, Wayne K., and Miskel, C. G. (2014). Administrasi Pendidikan; Teori, Riset, dan Praktik.

Khuriyah, Zamroni, dan S. (2016). Pengembangan Model Evaluasi Pengelolaan Pondok Pesantren. Jurnal Penelitian Dan Evaluasi Pendidikan, 20(1), 56-59.

Madjid, N. (1997). Bilik-Bilik Pesantren: Sebuah Potret Perjalanan. Jakarta: Paramadina.

Mardiyah. (2012). Kepemimpinan Kiai dalam Memelihara Budaya Organisasi. TSAQAFAH, 8(1), 67104.

Mastuhu. (1994). Dinamika Sistem Pendidikan Pesantren. Jakarta: INIS.

Pidarta, M. (2011). Manajemen Pendidikan Indonesia. Jakarta: Rineka Cipta.

Robbins, S. P. (1994). Teori Organisasi: Struktur, Desain, dan Aplikasi. Jakarta: Penerbit Arcan.

Royani, A. (2018). Eksistensi Pendidikan Pesantren dalam Arus Perubahan. Cendekia, 16(2), 375392.

Setyaningsih, R. (2016). Kontinuitas Pesantren dan Madrasah di Indonesia. At-Ta'dib, 11(1), 167183.

Sugiyono. (2008). Metode Penelitian Kuantitaif, Kualitatif dan R\&D. Bandung: Alfabeta.

Usman, H. (2011). Manajemen; Teori, Praktik, dan Riset Pendidikan (Ketiga; F. Yustianti, ed.). Jakarta: Bumi Aksara.

Widodo, H. (2019). Pendidikan Holistik Berbasis Budaya Sekolah. Yogyakarta: UAD Press.

Widodo, T. (2010). Pengaruh Lingkungan Kerja, Budaya Organiassi, Kepemimpinan, terhadap Kinerja: Studi Pada Pegawai Kecamat Sidorejo Kota Salatiga. Among Makarti, 3(5), 14-35.

Yatimah, D. (2011). Manajemen Pendidikan Pesantren dalam Upaya Peningkatan Mutu Santri. E/Hikmah, 9(1), 59-78.

Yunus, E. (2016). Manajemen Strategis. Yogyakarta: C.V. Andi Offset.

Zarkasyi, A. S. (2005). Manajemen Pesantren; Pengalaman Pondok Modern Gontor. Ponorogo: Trimurti Press.

Ziemek, M. (1986). Pesantren Dalam Perubahan Sosial. Jakarta: P3M. 